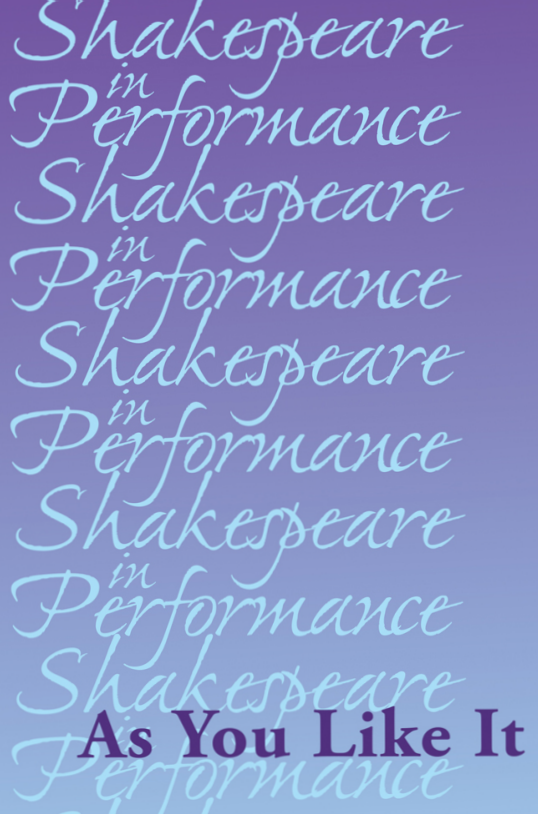

\title{
ROBERT SHAUGHNESSY
}

Robert Shaughnessy - 9781526115720 inchesterhive.com at 04/26/2023 01:05:48AM via free access 


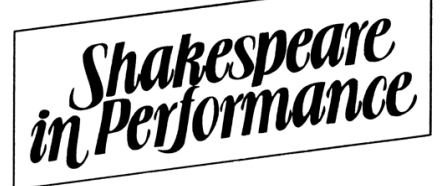

Founding editor: J. R. MULRYNE

General editors:

JAMES C. BULMAN, CAROL CHILLINGTON RUTTER

As You Like It

\section{MANCHESTER} 1824

Manchester University Press 
Already published in the series

Geraldine Cousin King John

Anthony B. Dawson Hamlet

Mary Judith Dunbar The Winter's Tale

Jay L. Halio A Midsummer Night's Dream (2nd edn)

Michael D. Friedman Titus Andronicus

Andrew Hartley Julius Caesar

Stuart Hampton-Reeves and Carol Chillington Rutter

The Henry VI plays

Bernice W. Kliman Macbeth (2nd edn)

Alexander Leggatt King Lear

James Loehlin Henry $V$

Scott McMillin Henry IV, Part One

Robert Ormsby Coriolanus

Lois Potter Othello

Hugh M. Richmond King Henry VIII

Margaret Shewring King Richard II

Virginia Mason Vaughan The Tempest 


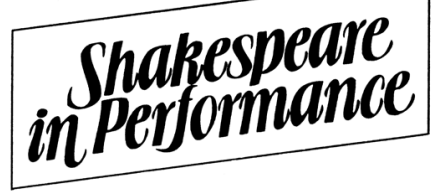

\section{As You Like It}

ROBERT SHAUGHNESSY

Manchester University Press 


\section{Copyright (C) ROBERT SHAUGHNESSY 2018}

The right of Robert Shaughnessy to be identified as the author of this work has been asserted by him in accordance with the Copyright, Designs and Patents Act 1988.

Published by Manchester University Press Altrincham Street, Manchester M1 7JA www.manchesteruniversitypress.co.uk

British Library Cataloguing-in-Publication Data A catalogue record for this book is available from the British Library

ISBN 9780719086939 hardback

First published 2018

The publisher has no responsibility for the persistence or accuracy of URLs for any external or third-party internet websites referred to in this book, and does not guarantee that any content on such websites is, or will remain, accurate or appropriate. 